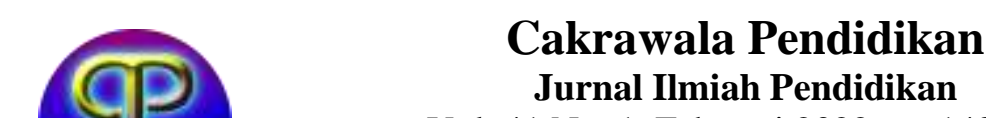

Vol. 41 No. 1, Februari 2022, pp.142-153

https://journal.uny.ac.id/index.php/cp/issue/view/2208

DOI: https://doi.org/10.21831/cp.v41i1.45912

\title{
How to educate students to become competent entrepreneurs
}

\author{
Endang Supardi*, Fahmi Jahidah Islamy, Sambas Ali Muhidin, Nani Sutarni \\ Universitas Pendidikan Indonesia \\ *Corresponding Author: endang-supardi@upi.edu
}

\begin{abstract}
The purpose of this study was to examine the direct or indirect effect of the entrepreneurship education variable towards the vocational high school students' entrepreneurship competence. This study used a quantitative approach with the Survey Method (Explanatory Survey Method), and the test uses path analysis. The number of samples in this study were 100 students from 25 Public and Private Vocational High Schools Accredited A in Bandung, Indonesia. The results showed that (1) entrepreneurship education had a significant effect on entrepreneurial intentions, both directly and indirectly, (2) entrepreneurship education had a significant direct effect on student entrepreneurial competencies, and (3) student entrepreneurial competencies had a significant influence on entrepreneurial intentions. This is because the results can illustrate that entrepreneurship education in vocational high schools is good, it can be seen from the score of the entrepreneurship education variable in the high category and the form of entrepreneurship learning in vocational high schools is good. Entrepreneurship education has the highest direct influence on students' entrepreneurial competence variables. Entrepreneurship education has a significant effect on entrepreneurial intentions, but if the competence variable becomes a mediating variable, it can further increase students' entrepreneurial intentions. The results of this study are expected to be considered by vocational high schools to provide entrepreneurship education to students. Thus, students' competence and interest in entrepreneurship can increase.
\end{abstract}

Keywords: entrepreneurship education, entrepreneurial intentions, student entrepreneurial competencies

\begin{tabular}{llll}
\hline Article history & & & \\
Received: & Revised: & Accepted: & Published: \\
15 September 2021 & 11 Oktober 2021 & 08 Januari 2022 & 28 Januari 2022 \\
\hline
\end{tabular}

Citation (APA Style): Supardi, E., Islamy, F. J., Muhidin, S. A., \& Sutarni, N. (2022). How to educate students to become competent entrepreneurs. Cakrawala Pendidikan: Jurnal Ilmiah Pendidikan, 41(1), 142153 https://doi.org/10.21831/cp.v41i1.45912

\section{INTRODUCTION}

Many people agree that promoting entrepreneurship in both developed and developing countries is necessary (Joshua et al., 2022). In developing countries such as Indonesia, entrepreneurship is a way to create jobs, leading to overcoming economic challenges, economic growth, and prosperity of the country. So, can the state encourage young people to become entrepreneurs? The answer needs to know whether young people, especially students, have entrepreneurial intentions (Ozaralli \& Rivenburgh, 2016). The decision to become an entrepreneur is something that is done consciously and requires careful planning. Entrepreneurship activities begin with entrepreneurial intentions formed through their competencies and an interacting environment ( $\mathrm{Al}$ Mamun et al., 2016). The education that is passed is a way to increase entrepreneurial competence (Boyles, 2012; Sánchez, 2013; Wang et al., 2019). Vocational high school is one of the schools having full of practicum (Ana, 2020; Rosina et al., 2021; Sangsawang, 2020). This school is a place of education for bringing potential sources of future entrepreneurs. This school is expected to influence and produce young people who have entrepreneurial intentions and have good entrepreneurial competencies (Rosina et al., 2021).

Entrepreneurship education intends to provide relevant entrepreneurial-driven knowledge, skills, and abilities (Wuryandani et al., 2016), along with agile, creative mindsets and other 
psychological aspects (for example, self-effacement, motivation, intentions) to enable the implementation of such innovations into a viable, entrepreneurial business. In other words, the effect of entrepreneurship education on entrepreneurial intentions is still limited and is still undergoing empirical testing (Zhang et al., 2014). Several studies (Bae et al., 2014; Cera et al., 2020; Joshua et al., 2022; Maresch et al., 2016; Westhead \& Solesvik, 2016; Zhang et al., 2014) discussed the effect of entrepreneurship education on entrepreneurial intention. However, few studies have been conducted, especially in Indonesia, on the effect of entrepreneurship education on entrepreneurial intentions by considering entrepreneurial competencies, especially in students.

There is a close linkage between vocational education institutions and the work environment (Maryanti \& Nandiyanto, 2021; Rosina et al., 2021). Vocational education is considered to be a bridge between society and the work environment (Maryanti \& Nandiyanto, 2021). [A3] [A4] The Indonesian Statistics Bureau (known as the Central Bureau of Statistics (BPS) stated that 9.1 million people $(6.49 \%)$ of the Indonesian workforce were unemployed in August 2021. Young people aged 15-24 years were the highest unemployed. The high unemployment rate in the young age group is due to limited employment opportunities and very low entrepreneurial competence and mentality (Al-Najar et al., 2019; Handayani et al., 2020). Vocational education, however, is supposed to provide graduates beneficial for industries since they offer skills ready to be used by employers (Dewi \& Sudira, 2018).

The relevance of the competence of vocational school graduates and the needs of the business and industrial world is one of the problems of Indonesian education. The research found that there are still around $12 \%$ of vocational school graduates who are not absorbed in the world of work, including the competence of vocational school graduates who are not following the needs of the business sector where these graduates work (Ngadi, 2014; Sukarjo \& Tarmana, 2021). The relatively low absorption of vocational high school graduates [A5] and high unemployment rates according to education levels are caused by many factors, such as the graduation level of Business and Management vocational students. Furthermore, the majority of graduates in Indonesia remains to be a job seeker instead of job creator so that vocational high schools can provide entrepreneurship education resulting in students having the competence and having the intention to be entrepreneurs. [A6]

Currently, many schools include entrepreneurship education in their curricula, to prepare students for work ready as entrepreneurs. However, there is still less research that discusses the study of learning and learning entrepreneurship from a scientific perspective. (Chaker \& Jarraya, 2021). The educational environment, experience, and teachers' attitude have not implemented an entrepreneurial education approach (Chaker \& Jarraya, 2021; Pittaway \& Cope, 2007), lack of clear understanding of entrepreneurship and entrepreneurship education.

The purpose of teaching with an entrepreneurial approach is expected to increase students' entrepreneurial competencies and entrepreneurial intention. Internal and external factors need to be considered (Sahabuddin et al., 2018). Entrepreneurship education is an external factor affecting students' intentions to become entrepreneurs. Although entrepreneurship education is recognized as important (Hills, 1988), there are empirical studies, which say that the impact of entrepreneurship education has a relatively little effect on entrepreneurial intentions. Many studies reveal that the influence of general education needs to be explored more. Regarding this, there is a need for an in-depth study of the management of entrepreneurship education. This study can be a factor influencing entrepreneurial intentions by considering the entrepreneurial competence of high school students.

The purpose of this study was to examine the direct and indirect effects among the variables of entrepreneurship education, students' entrepreneurial competence, and entrepreneurial intentions in the vocational school. This study used a quantitative approach with the Survey Method (Explanatory Survey Method), and the test uses path analysis. The novelties of this study were the use of the entrepreneurial competence variable as a mediating variable for the effect of entrepreneurship education on entrepreneurial intentions, the results obtained show that using the entrepreneurial competence variable can increase the influence of entrepreneurship education on students' entrepreneurial intentions, and the fact that it generates a new research model in which 
entrepreneurial competence is a significant factor to increase students' intention to become entrepreneurs.

\section{METHOD}

This study uses a quantitative approach with the Survey Method (Explanatory Survey Method). In this study, the unit of analysis serves as the unit of analysis in measuring each variable is the A-accredited vocational high school students in the Business and Management Expertise Sector in Bandung City. Of the 25 public and private vocational schools of business and management expertise, there are three state vocational schools and 22 private vocational schools. The sampling technique used was solving with an error rate of $10 \%$. Thus, the number of samples obtained was 100 vocational school students.

To collect primary data is done by submitting a questionnaire to the respondent. There are three [A7] variables in this study, namely entrepreneurship education (X), entrepreneurial competencies of the student (Y), and entrepreneurial intention (Z). This study uses a quantitative approach with a survey method. A five-point Likert scale was used to collect data which then were analyzed using path analysis.

\section{Table 1. Construct and measurement items}

\begin{tabular}{|c|c|}
\hline Construct & Measurement Items \\
\hline $\begin{array}{l}\text { Entrepreneurship } \\
\text { education }(\mathrm{X})\end{array}$ & $\begin{array}{l}\text { 1. Teachers have a creative spirit in shaping entrepreneurial learning. } \\
\text { 2. Teachers can transmit the courage of business risk to students. } \\
\text { 3. Teachers develop managerial skills to influence students. } \\
\text { 4. The teacher directs students to have a leadership spirit in entrepreneurship } \\
\text { learning. } \\
\text { 5. The teacher directs students to be able to anticipate the future in } \\
\text { entrepreneurship learning. }\end{array}$ \\
\hline $\begin{array}{l}\text { Entrepreneurial } \\
\text { competencies of } \\
\text { the student }(\mathrm{Y})\end{array}$ & $\begin{array}{l}\text { 1. Idea generation. } \\
\text { 2. Environmental scanning. } \\
\text { 3. Recognizing and envisioning taking advantage of opportunities. } \\
\text { 4. Formulating strategies for taking advantage of opportunities. } \\
\text { 5. Decision making and risk. }\end{array}$ \\
\hline $\begin{array}{l}\text { Entrepreneurial } \\
\text { intention }(Z)\end{array}$ & $\begin{array}{l}\text { 1. I will choose a career as an entrepreneur after passing later. } \\
\text { 2. I prefer being an entrepreneur in business myself to being an employee } \\
\text { company/organization. } \\
\text { 3. I expect to start my own business (entrepreneurial) in the next 1-3 years. }\end{array}$ \\
\hline
\end{tabular}

Based on the problems and the relationship of variables, the research model obtained is in Figure 1.

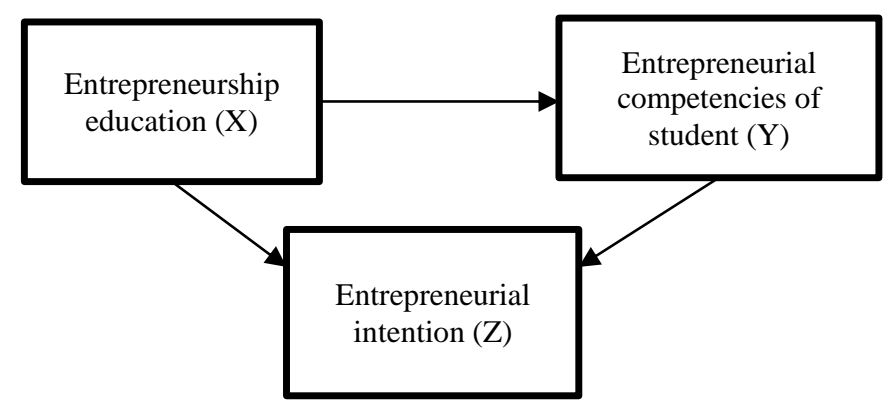

Figure 1. Research Model

A questionnaire is said to be reliable if the value of 's Alpha $>0.60$. As in Table 2, the value of Cronbach's Alpha is 0.844 and the number of question items is 13 questions. Thus, it is said that the questionnaire is reliable because $0.844>0.60$. 
Table 2. Validity and reliability

\begin{tabular}{cc}
\hline Cronbach's Alpha & $\mathrm{N}$ of Items \\
\hline 0.884 & 13 \\
\hline
\end{tabular}

Table 3. Validity test results

\begin{tabular}{|c|c|c|c|c|}
\hline \multicolumn{5}{|c|}{ Item-Total Statistics } \\
\hline & $\begin{array}{c}\text { Scale Mean if Item } \\
\text { Deleted }\end{array}$ & $\begin{array}{c}\text { Scale Variance if Item } \\
\text { Deleted }\end{array}$ & $\begin{array}{c}\text { Corrected Item-Total } \\
\text { Correlation }\end{array}$ & $\begin{array}{c}\text { Cronbach's Alpha if } \\
\text { Item Deleted }\end{array}$ \\
\hline Y1 & 46.1600 & 63.671 & 0.627 & 0.873 \\
\hline $\mathrm{Y} 2$ & 46.0700 & 63.763 & 0.596 & 0.874 \\
\hline Y3 & 46.1900 & 63.428 & 0.622 & 0.873 \\
\hline Y4 & 46.1900 & 66.054 & 0.519 & 0.878 \\
\hline Y5 & 46.1100 & 65.170 & 0.529 & 0.878 \\
\hline $\mathrm{Z1}$ & 46.2300 & 63.593 & 0.618 & 0.873 \\
\hline $\mathrm{Z} 2$ & 46.1900 & 66.075 & 0.498 & 0.879 \\
\hline $\mathrm{Z3}$ & 46.1600 & 64.681 & 0.575 & 0.876 \\
\hline $\mathrm{X} 4$ & 46.3300 & 66.244 & 0.493 & 0.880 \\
\hline $\mathrm{X} 5$ & 45.9800 & 64.545 & 0.608 & 0.874 \\
\hline $\mathrm{X} 1$ & 45.9900 & 64.515 & 0.585 & 0.875 \\
\hline $\mathrm{X} 2$ & 46.1200 & 65.460 & 0.568 & 0.876 \\
\hline X3 & 46.0400 & 64.402 & 0.564 & 0.876 \\
\hline
\end{tabular}

A measurement item is said to be valid if the Corrected item-total Correlation value is $\geq$ 0.30 (Khidzir et al., 2018). As in Table 2, the value of all items in the Corrected item-total Correlation question is $\geq 0.30$ out of a total of 13 question items. Thus, the questionnaire is valid.

\section{FINDING AND DISCUSSION}

Finding

Sub-structural Equation 1

Simultaneous influence

The effect of the variable entrepreneurship education on the variable entrepreneurial competencies of students simultaneously can be seen in Table 4, especially the R square value.

Table 4. Effect of simultaneous $X$ on $Y$

\begin{tabular}{ccccc}
\hline & \multicolumn{3}{c}{ Model Summary $^{\mathrm{b}}$} \\
Model & $\mathrm{R}$ & $\mathrm{R}$ Square & Adjusted R Square $^{\mathrm{S}}$ & Std. Error of the Estimate \\
\hline 1 & $0.784^{\mathrm{a}}$ & 0.615 & 0.611 & 0.46692 \\
a. Predictors: (Constant), X & & & \\
b. Dependent Variable: $\mathrm{Y}$ & & & \\
\hline
\end{tabular}

Table 4 shows that the value of $\mathrm{R}$ Square is 0.615 . This figure reveals the magnitude of the influence of the entrepreneurship education variable on the entrepreneurial competencies of students by calculating the coefficient of determination (KD) with the following formula:

$\mathrm{KD}=\mathrm{R}^{2} \mathrm{X} 100 \%$

$\mathrm{KD}=0,615 \times 100 \%$

$\mathrm{KD}=61,5 \%$

The influence of the entrepreneurship education variable towards the entrepreneurial competencies of students simultaneously is $61.5 \%$. Meanwhile, the remaining $38.5 \%$ is the influence of other factors. The following formula (1) is used to calculate the magnitude of the path coefficient for other variables outside of the study that affects it.

$$
\rho_{\gamma} \varepsilon_{1}=\sqrt{1-R_{x y}^{2}}
$$




$$
\begin{aligned}
& =\sqrt{1-0,615} \\
& =0,620
\end{aligned}
$$

Table 5. ANOVA

\begin{tabular}{llrrrrr}
\hline & Model & Sum of Squares & df & Mean Square & F & Sig. \\
\hline 1 & Regression & 34.105 & 1 & 34.105 & 156.434 & $0.000^{\mathrm{b}}$ \\
& Residual & 21.365 & 98 & 0.218 & & \\
& Total & 55.470 & 99 & & & \\
a. Dependent Variable: Y & & & & & \\
b. Predictors: (Constant), X & & & & & \\
\hline
\end{tabular}

The results of the significance test in the ANOVA table show that the sig. is 0.000 , thus it shows that the entrepreneurship education variable has a significant effect on the entrepreneurial competencies of the student variable.

\section{Partial influence}

Table 6. Partial influence

\begin{tabular}{ccccccc}
\hline & \multicolumn{7}{c}{$\begin{array}{c}\text { Unstandardized } \\
\text { Coefficients }\end{array}$} & \multicolumn{2}{c}{$\begin{array}{c}\text { Standardized } \\
\text { Coefficients } \\
\text { Bodel }\end{array}$} & B & Std. Error & Beta & t & Sig. \\
\hline 1 & (Constant) & 0.667 & 0.258 & & 2.587 & 0.011 \\
& X & 0.834 & 0.067 & 0.784 & 12.507 & 0.000 \\
\hline
\end{tabular}

a. Dependent Variable: Y

Based on Table 4, the variable $X$ has a value of Sig. of 0.000 . Compared with the value of $\alpha$, the value of sig. is smaller $(0.000<0.05)$. Thus, the significance and magnitude of the Beta (coefficient) of the path variable $\mathrm{X}$ to $\mathrm{Y}$ is $0.784\left(\rho_{y x}\right)$ so that the equation turns to be (2).

$\mathrm{Y}=\mathrm{Pyx}+\rho_{\gamma} \varepsilon_{1}$

$\mathrm{Y}=0,784 \mathrm{X}+0,62 \varepsilon_{1}$

So that we get a sub-structural Figure 2 along with the path coefficient

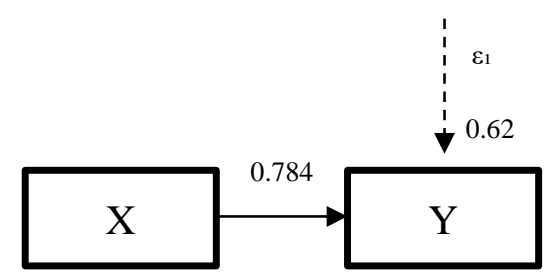

Figure 2. Sub-Structural 1 Path Analysis

\section{Sub-structural Equation 2}

$z=\rho_{z x} x+\rho_{z y} y+\rho_{z} \varepsilon_{2}$

Table 7. Summary model of $X$ and $Y$ variables concerning $Z$

\begin{tabular}{ccccc}
\hline Model & $\mathrm{R}$ & R Square & $\begin{array}{c}\text { Model Summary } \\
\text { Adjusted R Square }\end{array}$ & Std. Error of the Estimate \\
\hline 1 & $0.635^{\mathrm{a}}$ & 0.404 & 0.392 & 0.65415 \\
$\begin{array}{l}\text { a. Predictors: (Constant), Y, X } \\
\text { b. Dependent Variable: } \mathrm{Z}\end{array}$ & & \\
\hline
\end{tabular}

From Table 7, it is clear that the magnitude of $\mathrm{R}$ Square is 0.404 . This figure shows the magnitude of the influence of the entrepreneurship education (X) and entrepreneurial 
competencies of student $(\mathrm{Y})$ variables on Entrepreneurial Intention $(\mathrm{Z})$ by calculating the coefficient of determination (KD) with the following formula (3):

$\mathrm{KD}=\mathrm{R}^{2} \times 100 \% \ldots$
$\mathrm{KD}=0,404 \times 100 \%$
$\mathrm{KD}=40,4 \%$

This figure means that the influence of the variable entrepreneurship education $(X)$ and entrepreneurial competencies of the student $(\mathrm{Y})$ on entrepreneurial intention $(\mathrm{Z})$ simultaneously is $40.4 \%$. Meanwhile, the remaining $59.6 \%$ was the influence of other factors. The following formula is necessary to calculate the magnitude of the path coefficient for other variables outside the study that affects it.

$$
\begin{aligned}
\rho_{z} \varepsilon_{2} & =\sqrt{1-R_{x y}^{2}} \\
& =\sqrt{1-0,404} \\
& =0,772
\end{aligned}
$$

\begin{tabular}{|c|c|c|c|c|c|c|}
\hline \multicolumn{2}{|c|}{ Model } & Sum of Squares & $\mathrm{df}$ & Mean Square & $\mathrm{F}$ & Sig. \\
\hline \multirow[t]{3}{*}{1} & Regression & 28.114 & 2 & 14.057 & 32.850 & $0.000^{\mathrm{b}}$ \\
\hline & Residual & 41.507 & 97 & 0.428 & & \\
\hline & Total & 69.621 & 99 & & & \\
\hline & $\begin{array}{l}\text { ependent Var } \\
\text { edictors: (Ca }\end{array}$ & Z, Y, X & & & & \\
\hline
\end{tabular}

Table 8. ANOVA

The results of the significance test in the ANOVA Table 8 show that the sig. of 0.000 , thus the conclusion reveals that the entrepreneurship education variable $(X)$ and the entrepreneurial

\begin{tabular}{|c|c|c|c|c|c|c|}
\hline \multicolumn{7}{|c|}{ Coefficients $^{\mathrm{a}}$} \\
\hline \multirow{2}{*}{\multicolumn{2}{|c|}{ Model }} & Unst & d Coefficients & Standardized Coefficients & $\mathrm{t}$ & Sig. \\
\hline & & B & Std. Error & Beta & & \\
\hline \multirow[t]{3}{*}{1} & (Constant) & 0.953 & 0.373 & & 2.553 & 0.012 \\
\hline & $\mathrm{X}$ & 0.484 & 0.150 & 0.406 & 3.215 & 0.002 \\
\hline & $\mathrm{Y}$ & 0.297 & 0.142 & 0.265 & 2.097 & 0.039 \\
\hline \multicolumn{7}{|c|}{ a. Dependent Variable: $\mathrm{Z}$} \\
\hline
\end{tabular}
competencies of student $(\mathrm{Y})$ variable have a significant effect on entrepreneurial intention $(\mathrm{Z})$.

Table 9. Partial effect

The results shown in Table 9 reveals that the variable $X$ has a value of Sig. of 0.002 . This value of sig. is smaller than the value of $\alpha(0.002<0.05)$. Meanwhile, the $\mathrm{Y}$ variable has a Sig value. of 0.039 . When compared with the value of $\alpha$, the value of sig. is smaller than the value of $\alpha(0.039<0.05)$ Thus, the significance and magnitude of the Beta (coefficient) of the path variable $\mathrm{X}$ to $\mathrm{Z}$ is $0.406\left(\rho_{x z}\right)$ and the variance $\mathrm{Y}$ to $\mathrm{Z}$ is $0.265\left(\rho_{y z}\right)$ so that the equation becomes (4).

$$
\begin{aligned}
& \mathrm{Z}=\rho_{z x} x+\rho_{z x} Y+\rho_{\mathrm{Z}} \varepsilon_{2} \ldots \ldots \\
& \mathrm{Z}=0,406 \mathrm{X}+0,265 \mathrm{Y}+0,772 \varepsilon_{2}
\end{aligned}
$$

The structure of the influence of entrepreneurship education (X) and the variable entrepreneurial competencies of the student $(\mathrm{Y})$ on entrepreneurial intention $(\mathrm{Z})$ is seen in Figure 3. 


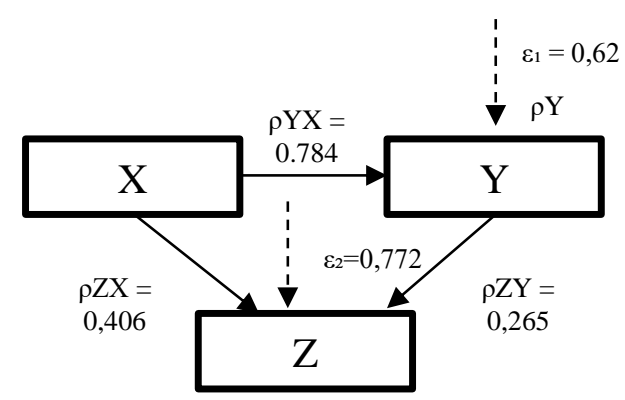

Figure 3. The Structure of The Influence of $X$ and $Y$ on $Z$ Along with The Path Coefficient

Table 1 provides a summary of the effect of entrepreneurship education and entrepreneurial competencies of student variables on entrepreneurial intention based on the SPSS approach. Entrepreneurship education on entrepreneurial intentions has a significant positive effect with a direct contribution of $40.6 \%$ which is included in the moderate category. Meanwhile, the indirect contribution value is $20.7 \%$. Thus, the total effect increases $61.3 \%$. Entrepreneurship education has a significant positive effect on students' entrepreneurial competence with a contribution of $78.4 \%$, which is included in the high category. Student entrepreneurial competence has a significant positive effect on entrepreneurial intentions with a direct contribution of $26.5 \%$, which is included in the low category.

\section{Discussion}

The general objective of the research conducted is to gain knowledge and conduct scientific studies on entrepreneurship education, entrepreneurial competencies, and entrepreneurial intentions. The description of each variable shows that all variables are in the high category. It means that the level of entrepreneurship education in vocational high schools and entrepreneurial competence influences the students' entrepreneurial intentions. Empirical data analysis re-established that the model of the influence of entrepreneurship education on entrepreneurial intention empirically fits the data. The students' choice of becoming an entrepreneur after graduation indicates the significant effect of entrepreneurship education on interest in entrepreneurship.

Entrepreneurship education must include an elaborative national strategic plan that supports entrepreneurship education programs, the preparation of teachers with elaboration skills, curricula, and the creation of teaching aids in the learning process (Bikse et al., 2014). Teachers as educators must have the ability to develop basic creativity skills such as fluency in thinking, original thinking, and flexible thinking. It shows that creativity training plays a significant role in entrepreneurship education (Turcan \& Fraser, 2018).

In this case, the teacher is considered capable of creating learning innovations (Estrellan et al., 2021; Lumbu-ani et al., 2021; Mohamad \& Masek, 2021; Nuhu, K. M., \& Onojah, 2022). They also must have a creative spirit in forming entrepreneurial learning. They can transmit the courage of business risks to students and direct students to have a leadership spirit, to improve student competence (Heinonen, 2007; Heinonen \& Poikkijoki, 2006). A learning process must consider strategy, system design (T. Ismail \& Ghozali, 2015), both in the form of learning interactions, classroom management, utilization of learning resources, and assessments (Heinonen, 2007; Heinonen \& Poikkijoki, 2006). Therefore, a teacher needs adequate knowledge and skills in learning management. The results of the study indicate that entrepreneurship education has a significant effect on entrepreneurial competencies. Furthermore, some reports explained that in business in general people work in existing organizations, guided by existing routines and structures (Morris et al., 2013), whereas entrepreneurs create new organizations and have their responsibility to determine what activities will be carried out and managed to keep the organization structured, how resources are allocated, find the right resources, and other decisions, so that accurate entrepreneurship education can develop entrepreneurial competencies to support 
them.

The studies carried out (Sánchez, 2013) contribute to research on entrepreneurship education by revealing the benefits that students can get from entrepreneurship programs. The study describes a quantitative assessment that entrepreneurship education which has a positive and significant relationship to entrepreneurial competencies. Early introduction of entrepreneurship education to undergraduate students at universities in Singapore has a positive effect on changing perceptions, entrepreneurial intentions, and entrepreneurial competencies among Singapore students.

Empirical research has shown that the existence of general education and special programs on entrepreneurship has a positive effect on students' entrepreneurial intentions. In every educational activity, it is suggested to be able to promote EI (entrepreneurial intention) because entrepreneurship is related to knowledge and skills that stimulate individual motivation to create a new business effort (Zhang et al., 2014). Entrepreneurship can be learned or at least encouraged through education. Students taking entrepreneurship education indeed show a greater intention to start a business (Bae et al., 2014; Cera et al., 2020; Westhead \& Solesvik, 2016; Zhang et al., 2014), this is in line with the results of research that entrepreneurship education affects entrepreneurial intentions.

We need to know self-skills to become a successful entrepreneur and to be able to selfreflection about the potential of entrepreneurial competence (V. Y. Ismail et al., 2015). Competence is something positive in a person. It is a talent that makes our work go well. Competence is the knowledge, abilities, characteristics, and attitude concerning the requirement for good performance, especially in entrepreneurship. Some researchers claim that entrepreneurial competencies are necessary to start a business (Inyang \& Enuoh, 2009; Man \& Lau, 2000; Sánchez, 2011), whereas some argue that a business requires managerial competence (Kræmmergaard \& Rose, 2002; Lau \& Chan, 2002; Zacca \& Dayan, 2018). Other opinions suggest that entrepreneurship requires competence in these two areas (Man \& Lau, 2005; Mitchelmore \& Rowley, 2010; Pansiri \& Temtime, 2008). But opinion (Draksler \& Sirec, 2021), focuses on entrepreneurial context on the individual, while the management context focuses on the organization. Competence is learnable. Therefore, education is the first way in providing a theoretical basis for student competence to start entrepreneurship. Research results (Al Mamun et al., 2016; Draksler \& Sirec, 2021; Sánchez, 2013) confirmed that students who had higher levels of EC (in terms of knowledge and skills) have a higher level of entrepreneurial intention.

\section{CONCLUSION}

Entrepreneurship education has a significant effect on entrepreneurial intentions both directly and indirectly. However, the influence of entrepreneurial education on entrepreneurial intentions through entrepreneurial competence has a lower effect. In terms of direct effect, entrepreneurial education has a significant direct impact on students' entrepreneurial competence. Student entrepreneurial competence has a direct influence directly significant to entrepreneurial intention and entrepreneurship education. For entrepreneurship education to be optimal, teachers must facilitate students to develop a leadership spirit in entrepreneurship learning. Thus, students' entrepreneurial competencies increase. They can recognize and imagine opportunities and formulate strategies to take advantage of opportunities. They must consider increasing entrepreneurial intentions and be eager to start entrepreneurship in the next 1-3 years. Therefore, one of the efforts to improve teacher teaching activities in terms of elaboration skills and fluent thinking skills is to prepare learning materials to be taught with careful preparation, not forgetting to look for other sources of material, so that when giving answers, opinions, or presenting material could be better. Suggestions for further researchers to prepare themselves in increasing student motivation and the role of the environment so that improvements to some things that are considered not good or not optimal in their implementation will provide better results and give benefits for various parties, and with what will be the objectives of learning activities. 


\section{REFERENCES}

Al-Najar, H., Khalil, H., \& Rahayu, Y. S. (2019). High unemployment records of graduated students in the development of urban agriculture in the Gaza strip. Indonesian Journal of Science and Technology, 4(2), 196-203. https://doi.org/10.17509/ijost.v4i2.18176

Al Mamun, A., Binti Che Nawi, N., Dewiendren, A. A., \& Fazira Binti Shamsudin, S. F. (2016). Examining the effects of entrepreneurial competencies on students' entrepreneurial intention. Mediterranean Journal of Social Sciences, 7(2), 119-127. https://doi.org/10.5901/mjss.2016.v7n2p119

Ana, A. (2020). Trends in expert system development: A practicum content analysis in vocational education for over grow pandemic learning problems. Indonesian Journal of Science and Technology, 5(2), 246-260. https://doi.org/10.17509/ijost.v5i2.24616

Bae, T. J., Qian, S., Miao, C., \& Fiet, J. O. (2014). The relationship between entrepreneurship education and entrepreneurial intentions: A meta-analytic review. Entrepreneurship Theory and Practice, 38(2), 217-254. https://doi.org/10.1111/etap.12095

Bikse, V., Riemere, I., \& Rivza, B. (2014). The Improvement of Entrepreneurship Education Management in Latvia. Procedia - Social and Behavioral Sciences, 140, 69-76. https://doi.org/10.1016/j.sbspro.2014.04.388

Boyles, T. (2012). 21 st century knowledge, skills, and abilities and entrepreneurial competencies: A model for undergraduate entrepreneurship education. Journal of Entrepreneurship Education, 15, $41-56$.

https://www.researchgate.net/publication/283749492_21_st_century_knowledge_skills_and_abil ities_and_entrepreneurial_competencies_A_model_for_undergraduate_entrepreneurship_educati on

Cera, G., Mlouk, A., Cera, E., \& Shumeli, A. (2020). The impact of entrepreneurship education on entrepreneurial intention. A quasi-experimental research design. Journal of Competitiveness, 12(1), 39-56. https://doi.org/10.7441/joc.2020.01.03

Chaker, H., \& Jarraya, H. (2021). Combining teaching "about" and "through" entrepreneurship: A practice to develop students' entrepreneurial competencies. Industry and Higher Education, 35(4), 432-442. https://doi.org/10.1177/0950422221991005

Dewi, S. S., \& Sudira, P. (2018). The contribution of teaching factory program implementation on work readiness of vocational high school students in Makassar. Journal of Educational Science and Technology (EST), 4(2), 126-131. https://doi.org/10.26858/est.v4i2.6434

Draksler, T. Z., \& Sirec, K. (2021). The study of entrepreneurial intentions and entrepreneurial competencies of business vs. non-business students. Journal of Competitiveness, 13(2), 171-188. https://doi.org/10.7441/JOC.2021.02.10

Estrellan, A., Ferrariz, K. J., Lazona, P. A., Madres, V. E., \& Estrellan, J. C. (2021). E-learning amidst the pandemic: Teachers' perspective in the Philippines. ASEAN Journal of Science and Engineering Education, 1(2), 93-96. https://doi.org/10.17509/ajsee.v1i2.33384

Handayani, M. N., Ali, M., Wahyudin, D., \& Mukhidin, M. (2020). Green skills understanding of agricultural vocational school teachers around West Java Indonesia. Indonesian Journal of Science and Technology, 5(1), 21-30. https://doi.org/10.17509/ijost.v5i1.22897

Heinonen, J. (2007). An entrepreneurial-directed approach to teaching corporate entrepreneurship at university level. Education and Training, 49(4), 310-324. https://doi.org/10.1108/00400910710754453

Heinonen, J., \& Poikkijoki, S. A. (2006). An entrepreneurial-directed approach to entrepreneurship education: Mission impossible? Journal of Management Development, 25(1), 80-94. https://doi.org/10.1108/02621710610637981 
Hills, G. E. (1988). Variations in university entrepreneurship education: An empirical study of an evolving field. Journal of Business Venturing, 3(2), 109-122. https://doi.org/10.1016/0883-9026(88)90021-3

Inyang, B. J., \& Enuoh, R. O. (2009). Entrepreneurial Competencies: The Missing Links to Successful Entrepreneurship in Nigeria. International Business Research, 2(2). https://doi.org/10.5539/ibr.v2n2p62

Ismail, T., \& Ghozali, I. (2015). Control system, strategy and learning. Academy of Strategic Management Journal, 14(1), 58-72.

Ismail, V. Y., Zain, E., \& Zulihar. (2015). The Portrait of Entrepreneurial Competence on Student Entrepreneurs. Procedia - Social and Behavioral Sciences, 169(August 2014), 178-188. https://doi.org/10.1016/j.sbspro.2015.01.300

Joshua, A. B., Olabo, O. O., Ochayi, O. A., Musiliu, A. A., \& Aderogba, O. A. (2022). Barriers limiting the use of Google Classroom for learning vocational and entrepreneurship courses. ASEAN Journal of Science and Engineering Education, 2(1), 61-74. https://doi.org/https://dx.doi.org/10.\%2017509/xxxxt.vxix

Khidzir, K. A. M., Ismail, N. Z., \& Abdullah, A. R. (2018). Validity and reliability of instrument to measure social media skills among small and medium entrepreneurs at Pengkalan Datu River. International Journal of Development and Sustainability, 7(3), 1026-1037.

Kræmmergaard, P., \& Rose, J. (2002). Managerial Competences for ERP Journeys. Information Systems Frontiers, 4(2), 199-211. https://doi.org/10.1023/A:1016054904008

Lau, T., \& Chan, K. F. (2002). Managerial Competence of SME Owner/Manager-Does Regional Context Matter? Journal of Small Business and Entrepreneurship, 16(2), 7793. https://doi.org/10.1080/08276331.2002.10593304

Lumbu-ani, J., Abusama, H. P., Pangarungan, J. L., Danozo, J. J. L., Estrada, M. J. L., Hasan, H. A., \& Moscoso, L. H. A. (2021). Attitude of Sultan Kudarat State University laboratory high school students and teachers on proposed "no homework policy" bill. Indonesian Journal of Educational Research and Technology, 1(2), 45-50. https://doi.org/10.17509/ijert.v1i2.33407

Man, T. W. Y., \& Lau, T. (2000). Entrepreneurial Competencies of Sme. Journal of Enterprising Culture, 8(3), 235-254.

Man, T. W. Y., \& Lau, T. (2005). The context of entrepreneurship in Hong Kong: An investigation through the patterns of entrepreneurial competencies in contrasting industrial environments. Journal of Small Business and Enterprise Development, 12(4), 464-481. https://doi.org/10.1108/14626000510628162

Maresch, D., Harms, R., Kailer, N., \& Wimmer-Wurm, B. (2016). The impact of entrepreneurship education on the entrepreneurial intention of students in science and engineering versus business studies university programs. Technological Forecasting and Social Change, 104, 172-179. https://doi.org/10.1016/j.techfore.2015.11.006

Maryanti, R., \& Nandiyanto, A. B. D. (2021). Curriculum development in science education in vocational school. ASEAN Journal of Science and Engineering Education, 2(1), 151-156. https://doi.org/10.17509/ajsee.v1i3.38429

Mitchelmore, S., \& Rowley, J. (2010). Entrepreneurial competencies: A literature review and development agenda. International Journal of Entrepreneurial Behaviour \& Research, 16(2), 92-111. https://doi.org/10.1108/13552551011026995

Mohamad, N., \& Masek, A. (2021). Modes of facilitator skills for group learning among design and technology teachers in secondary schools. Indonesian Journal of Teaching in Science, l(1), 17-20. https://doi.org/10.17509/ijotis.v1i1.33580 
Morris, M. H., Webb, J. W., Fu, J., \& Singhal, S. (2013). A competency-based perspective on entrepreneurship education: Conceptual and empirical insights. Journal of Small Business Management, 51(3), 352-369. https://doi.org/10.1111/jsbm.12023

Ngadi, N. (2014). Relevansi pendidikan kejuruan terhadap pasar kerja di kota Salatiga. Kependudukan Indonesia Journal, 9(1), 59-70. https://doi.org/https://doi.org/10.14203/jki.v9i1.11

Nuhu, K. M., \& Onojah, A. O. (2022). Availability, accessibility, and utilization of intelligent tutoring system for instruction among secondary school teachers in Ilorin, Kwara State, Nigeria. Indonesian Journal of Multidiciplinary Research, 2(2), 271-282. https://doi.org/https://doi.org/10.17509/ijomr.v2i2.38643

Ozaralli, N., \& Rivenburgh, N. K. (2016). Entrepreneurial intention: Antecedents to entrepreneurial behavior in the U.S.A. and Turkey. Journal of Global Entrepreneurship Research, 6(1). https://doi.org/10.1186/s40497-016-0047-x

Pansiri, J., \& Temtime, Z. T. (2008). Assessing managerial skills in SMEs for capacity building. Journal of Management Development, 27(2), 251-260. https://doi.org/10.1108/02621710810849362

Pittaway, L., \& Cope, J. (2007). Entrepreneurship education: A systematic review of the evidence. International Small Business Journal: Researching Entrepreneurship, 25(5), 479-510. https://doi.org/10.1177/0266242607080656

Rosina, H., Virgantina, V., Ayyash, Y., Dwiyanti, V., \& Boonsong, S. (2021). Vocational education curriculum: Between vocational education and industrial needs. ASEAN Journal of Science and Engineering Education, 1(2), 105-110. https://doi.org/10.17509/ajsee.v1i2.33400

Sahabuddin, R., Thaha, S., Nurjaya, \& Fatmawati. (2018). Effect of visual learning style and school climate on students' achievement of learning entrepreneurship at SMKN 1 Palangga. Journal of Entrepreneurship Education, 21(3), 1-13. https://www.abacademies.org/articles/effectof-visual-learning-style-and-school-climate-on-students39-achievement-of-learningentrepreneurship-at-smkn-1-palangga-7354.html

Sánchez, J. C. (2011). University training for entrepreneurial competencies: Its impact on intention of venture creation. International Entrepreneurship and Management Journal, 7(2), 239-254. https://doi.org/10.1007/s11365-010-0156-x

Sánchez, J. C. (2013). The impact of an entrepreneurship education program on entrepreneurial competencies and intention. Journal of Small Business Management, 51(3), 447-465. https://doi.org/10.1111/jsbm.12025

Sangsawang, T. (2020). An instructional design for online learning in vocational education according to a self-regulated learning framework for problem solving during the COVID-19 crisis. Indonesian Journal of Science and Technology, 5(2), 283-298. https://doi.org/10.17509/ijost.v5i2.24702

Sukarjo, S. T., \& Tarmana, D. (2021). Analisis daya serap dunia kerja terhadap alumni SMK Negeri 1 Tukak Sadai tahun 2014 - 2020. JURNAL PENDIDIKAN ROKANIA, 6(1), 121132. https://doi.org/https://doi.org/10.37728/jpr.v6i1.408

Turcan, R. V., \& Fraser, N. M. (2018). The Palgrave handbook of multidisciplinary perspectives on entrepreneurship. The Palgrave Handbook of Multidisciplinary Perspectives on Entrepreneurship, 1-525. https://doi.org/10.1007/978-3-319-91611-8

Wang, S.-M., Yueh, H.-P., \& Wen, P.-C. (2019). How the new type of entrepreneurship education complements the traditional one in developing entrepreneurial competencies and intention. Frontiers in Psychology, 10(September), 1-12. https://doi.org/10.3389/fpsyg.2019.02048

Westhead, P., \& Solesvik, M. Z. (2016). Entrepreneurship education and entrepreneurial intention: Do female students benefit? International Small Business Journal: Researching Entrepreneurship, 34(8), 979-1003. https://doi.org/10.1177/0266242615612534 
Wuryandani, W., Fathurrohman, F., \& Ambarwati, U. (2016). Implementasi pendidikan karakter kemandirian di Muhammadiyah Boarding School. Jurnal Cakrawala Pendidikan, 15(2), 208-216. https://doi.org/10.21831/cp.v15i2.9882

Zacca, R., \& Dayan, M. (2018). Linking managerial competence to small enterprise performance within the dynamic capability logic. Journal of Small Business and Enterprise Development, 25(2), 256-276. https://doi.org/10.1108/JSBED-02-2017-0042

Zhang, Y., Duysters, G., \& Cloodt, M. (2014). The role of entrepreneurship education as a predictor of university students' entrepreneurial intention. International Entrepreneurship and Management Journal, 10(3), 623-641. https://doi.org/10.1007/s11365-012-0246-z 